\title{
Effect of different dietary protein level on the growth performance of broiler chickens
}

PRADEEP KUMAR, NAZIM ALI, RAJKUMAR, JAGDEEP KUMAR, MANOJ KUMAR BANSALA AND PRAVEEN KUMAR

ABSTRACT : The present study was conducted at Sardar Vallabhbhai Patel University of Agriculture and Technology, Meerut (India) to compare the growth performance of broiler chicken after feeding them on four dietary treatments viz., $\mathrm{T}_{1}$ (control) containing 22 per cent crude protein $(\mathrm{CP}), \mathrm{T}_{2} 85$ per cent control diet +7.5 per cent groundnut cake +7.5 per cent fish meal $(25 \%$ $\mathrm{CP}), \mathrm{T}_{3} 83$ per cent control diet +8.5 per cent maize +8.5 per cent wheat $(20 \% \mathrm{CP})$ and $\mathrm{T}_{4} 66.5$ per cent control diet +33.5 per cent wheat $(18 \% \mathrm{CP})$. Average body weight gain of broiler chicks of 6 week age, fed control diet ( $22 \% \mathrm{CP}), 25,20$ and 18 per cent CP were reported $2062 \pm 4.1,2174 \pm 4.9,1875 \pm 4.0$ and $1780 \pm 2.8 \mathrm{~g}$ against the feed consumption of $3727 \pm 1.4,4243.9 \pm 20.7,3432 \pm$ 14.3 and $3396 \pm 11.4 \mathrm{~g}$, respectively. The average $\mathrm{FCR}$ of control diet $\mathrm{T}_{2}, 25, \mathrm{~T}_{3}, 20$ and $\mathrm{T}_{4} 18$ per cent $\mathrm{CP}$ were $1.94 \pm 0.00,1.83 \pm 0.01$, $1.89 \pm 0.01$ and $1.75 \pm 0.07$, respectively.

KEY WORDS : Broiler chick, Feed consumption, Body weight gain, FCR

HOW TO CITE THIS PAPER : Kumar, Pradeep, Ali, Nazim, Rajkumar, Kumar, Jagdeep, Bansala, Manoj Kumar and Kumar, Praveen (2015). Effect of different dietary protein level on the growth performance of broiler chickens. Res. J. Animal Hus. \& Dairy Sci., 6(1) : 48-51.

Address for correspondence :

Pradeep Kumar, Department of Animal Husbandry, Sardar Vallabhbhai Patel University of Agriculture and Technology, Modipuram, MEERUT (U.P.) INDIA

Associated Authors' :

Nazim Ali, Rajkumar, Jagdeep Kumar, Manoj Kumar Bansala and Praveen Kumar, Department of Animal Husbandry, Sardar Vallabhbhai Patel University of Agriculture and Technology, Modipuram, MEERUT (U.P.) INDIA 